\title{
Intellectual Capital in the Post COVID-19
}

\author{
María Luisa Quintero Soto ${ }^{1 *}$, Leticia María González Velázquez² and Cruz García Lirios ${ }^{3}$ \\ ${ }^{1}$ Nezahualcóyotl Professional Academic Unit/Autonomous University of the State of Mexico, Mexico \\ 2Secretary, MA Antonia Camargo Pacheco, Mexico \\ ${ }^{3}$ Research and Professor, Autonomous University of the State of Mexico (UAEM), Mexico
}

*Corresponding author: Dr. maria Lusia Quintero Soto, Nezahualcóyotl Professional Academic Unit/Autonomous University of the State of Mexico, Mexico; Email: mlquinteros@uemex.mx

Received: February 22, 2021; Accepted: March 12, 2021; Published: March 19, 2021

\begin{abstract}
Social Work studies about entrepreneurship warn a process of deliberate, planned and systematic rational choice which promote intellectual capital formation are predominant determinants. Specify a model for the study of trust dimensions: experiences, knowledge, capabilities, emotions, and abilities. Not experimental, documentary and retrospective study with a nonrandom selection of sources indexed repositories, considering the keywords and the publication period 2015-2020. A model with eight hypotheses three paths dependency relationships between nine variables put forward in the state of knowledge was specified.
\end{abstract}

Keywords: Heads of family, Social work, Entrepreneurship, Specific-19ation, Model

\section{Introduction}

The aim of this study is to specify a model for the study of social entrepreneurship in household heads [1]. From a review of the literature, the variables that allowed the systematization of the determinants of entrepreneurship paths are extracted [2].

The study is part of the Division of Humanities and Social Sciences, Social Work discipline, area of health promotion and subarea of promotion of reproductive rights, parental rearing styles and management of household heads [3].

However, the project also has interference in economic and administrative sciences, as it will recover in the second phase the effect of cooperative entrepreneurship in Human Development with an emphasis on reproductive health, family upbringing and training of entrepreneurs [4].

\section{Theory of Intellectual Capital}

The principles that guide the rational choice lie in the tastes and preferences crystallizing objectives of the actors [5]. Therefore, before taking any decision binding preferences strategies, achieve collect information that will determine the election [6]. If individuals rather have an indeterminate number of tastes, objectives and goals, then your preference swill no longer depend on their capacity of choice and action [7]. Therefore, they act in a non-rational way [8].

The rational choice theory also warns that a decision is a result of an estimate of the costs and benefits of carrying out an effort regardless of their degree of significance [9]. This is a utilitarian dimension in which control of a situation from establishing a favorable balance of benefits versus costs will determine the election [10].
More specifically, the benefits and costs translate into a ratio of risk, effort and reward [11]. This means that a choice be rational when the risks and efforts are minimal provided that the rewards are greater [12].

In contrast, when the recognition of an effort and risk not up to expectations, then the choice has not been entirely rational and rather approaches an irrational dimension if the risks and efforts are increasing and intense with respect to the absence of rewards [13].

This is because the individual who tries is committed to the risks that will be activated by profit expectations [14].

Integrating each of the variables represents a series of paths in which the correlations explain each choice [15]. In short, the rational choice explained in general terms the process by which preferences are the determining factor by other factors which generate information or sense an atmosphere of certainty when deciding and act accordingly [16]. To the extent such information is available, accessible and actionable, then the rational choice will emerge as an option, but rather proliferates ambiguity, then a non - rational decision will be generated with irrational consequences [17].

However, when information is not available or is very abstract, rational choice is replaced by a tighter option to culture; values and norms of people with respect to a contingency which no known precedent some, but people always react the same way [18].

\section{Studies of Intellectual Capital}

If rational choice is brewing from preferences based on information available to determine tastes and objectives, the prospective attitude suggests that the absence of information creates uncertainty that determine risk aversion or waiver of certain gains and risk appetite when losses are imminent [19]. Thus, the utility, benefit or happiness 
crystallize into losses or gains, circumventing the process of rational choice and legitimizing an irrational choice [20].

Therefore, a prospective is more than a decision lies in attitude and expectation of risk or certainty to gains and losses in the immediate future. In that sense, a retrospective is an attitude that is the same relations but compared to last [21].

In short, the prospective attitude is a hinge between rational choice and reasoned action. Each of these theoretical and conceptual frameworks based its scope and limits from the availability of information, if the individual is able to assume an attitude, make a decision or take an action that corresponds to the available information and representation that you have it [22].

\section{Specification a Model for Study of Intellectual Capital}

Unlike the rational choice theory that focuses on the usefulness of the information available and the theory of prospective attitude that focuses its interest in the certainty of the information, the theory of reasoned action assumes that information, any it is, it is a general environment that will influence the behavior to the extent that information is transformed into rules. This is because the theory of reasoned action considers that all information is cognitively process [23].

Therefore, an overview of the environment, their demands and opportunities conducive categories of accessible and abundant availability of information that will influence a spendthrift behavior such as believing that jobs, wages and financial credits significantly increase [24]. On the contrary, if one considers that the context is rather recession and economic crisis, then austere styles, cooperative and innovative life will be adopted [25].

However, the theory of reasoned action, like the rational choice theory and the theory of prospective attitude, pose a general scenario incident on a specific behavior without considering the current situation and specifies decision maker [26].

\section{Method}

Documentary work was carried out with a selection of sources indexed to international repositories such as Scopus and WoS, considering the keywords of "specification" and "intellectual capital" in the period from 2015 to 2020

A search for summaries was carried out in order to subtract the indicators of intellectual capital, considering equation (1). Then, once the indicators of empathy, trust, commitment, entrepreneurship, productivity, competitiveness, innovation, satisfaction and happiness were selected, experts on the subject rated these indicators in order of importance, being 10 of greater importance and 0 of zero or no some importance Data were processed in the statistical analysis package for social sciences version 20.0 :

$$
H^{s^{\prime}}=b(1-u) H^{s}
$$

b: efficiency of $\mathrm{HC}$ accumulation process, exog. parameter. 1-u: time devoted in acquiring $\mathrm{HC}$.
Percentages, contingencies and proportions were estimated to establish risk thresholds in decision-making regarding intellectual capital indicators.

\section{Results}

The trust indicator obtained the highest percentage (25\%) followed by commitment (22\%), empathy (17\%), entrepreneurship (13\%), satisfaction (9\%), innovation (6\%), productivity (4\%), competitiveness (3\%), happiness (1\%). This means that decision-making is a function of the level of trust, although the instrument does not specify the type of trust that can be organizational, interpersonal, intra-personal or technological.

The contingency parameters suggest significant differences between the decisions made based on intrapersonal trust with respect to interpersonal $[\varkappa 2=16,27(16 \mathrm{df}) \mathrm{p}<, 05]$. In other words, as an educational process, intellectual capital is focused on internal capacities, experiences, skills, knowledge and emotions rather than their outsourcing when socializing knowledge.

The proportions of probability suggest that the formative process of intellectual capital, centered on the intra-personal confidence of abilities [OR $=17,21(13,24$ to 19,20$)]$, skills [OR $=18,21(14,35$ to $20,21)$ ], knowledge [OR $=15,43(13,24$ to 21,23$)]$, experiences [OR $=18,20(14,32$ to 23,45$)]$ and emotions $[15,46(10,21$ to 22,31$)]$, is at an allowable threshold of risk. It means then that the intervention of social work can be cemented in the formation of intellectual capital and its indicators of intra-personal confidence.

\section{Discussion}

The contribution of the present work to the state of the matter lies in the specification of a model for the study of intellectual capital, considering the dimensions of intra-personal confidence in which skills, emotions, experiences, abilities and knowledge, in the qualification of experts, were located in tolerable risk thresholds.

In relation to the literature where the intellectual captain is approached from non-formative organizational dimensions such as cooperation, tasks, goals, objectives or innovations, this paper suggests complementing these dimensions with intra-personal ones to establish differences between professional training and job training.

Future lines of research concerning the structural models of intellectual capital, human capital and social capital will allow establishing a predictive explanation of academic, professional and labor training.

\section{Conclusion}

Given that the information is not available or is processable actors requiring immediate planning of their actions, the determinants of the planned behavior are those in which information can be delimited and specified depending on a particular situation or to an event which is the subjective control from decision-making and the information available and actionable [18].

The theory of planned behavior finds that perceived control is a significant determinant of behavior in direct and indirect mode. To 
interact with subjective norms and attitudes generate an intention that is also assumed as a determinant of behavior [19].

However, it perceived control, as the norm and attitude, depend on a set of beliefs about information availability. In this sense, the specification of a model would include variables that anticipate the behavior, but not from the beliefs of availability of information, but from provisions to cooperate by actors that form an entrepreneurial project to develop their skills, not only of choice, deliberation or planning, but innovation [20].

\section{References}

1. Andersen HC (1945) Kejsarens nya kläder, (The emperors new clothes, authors transl.) in H.C. Andersen och hans sagor, Bokförlaget Norden, Malmö. Band 172178: 1 .

2. Bonoma TV, Clark BC (1988) Marketing Performance Assessment, Boston: Harvard.

3. Bontis Nick (1998) Intellectual capital: an exploratory study that develops measures and models. Management Decision 36/2: 63-76.

4. Booth, Rupert (1998) The measurement of intellectual capital. Management Accounting 26-28.

5. Boudreau, John (1998) Strategic Human Resource Management Measures: Key Linkages to the People Vantage Model. Journal of Human Resource Costing \& And Accounting 3: 21-40.

6. Davenport TH, Prusak L (1998) Working Knowledge: How Organizations Manage What They.

7. Dinesh, David, Palmer, Elaine (1998) Management by objectives and the Balanced Scorecard: Will Rome fall again? Management Decision 36/6: 363-369.

8. Eccles Robert (1991) The performance measurement manifesto. Harvard Business Review 131-138.

9. Edvinsson Leif, Malone, Michael S (1997) Intellectual capital - Realizing your company's true value by finding its hidden roots. Harper Business, New York.

10. Edvinsson Leif, Malone, Michael S (1998) Intellectual capital - The proven way to establish your company's real value by measuring its hidden brainpower. Piatkus Publ. New York.
11. Frankfort-Nachmias, Chava; Nachmias, David (1992) Research methods in the social sciences. St Martin's Press. Kent.

12. Gröjer, Jan-Erik; Johansson, Ulf (1996) Human resource costing and accounting. Joint Industrial Safety Council, Stockholm.

13. Hemmer, Thomas (1996) On the design and choice of 'modern' management accounting measures. Journal of Management Accounting Research 8: 87-116.

14. Hollis, Martin (1994) The philosophy of social science. Cambridge University Press.

15. Johansson U, Mabon, H (1998) The personnel Economics Institute After Ten Years: What Has Been Achieved and Where Are We Going? Journal of Human Resource Costing \& And Accounting 3: 65-76.

16. Johnson H, Thomas Kaplan, Robert (1987) Relevance lost the rice and fall of management accounting, Harvard Business School Press, cop. Boston.

17. Kaplan, Robert Norton, David (1992) The Balanced Scorecard - Measures that drive performance. Harvard Business Review 1: 71-79.

18. Kaplan, Robert Norton, David (1996a) Using the balanced scorecard as a strategic management system. Harvard Business Review 75-86.

19. Kaplan, Robert Norton, David (1996b) The balanced scorecard. Harvard Business School Press, Boston.

20. Leininger, Madeleine (1994) Evaluation Criteria and Critique of Qualitative Research Studies, Critical Issues in Qualitative Research Methods edited by Morse, Janice, Thousands Oak, Calif. Sage.

21. Liberatore Matthew, Monaham, Thomas Tymon, Walter (1997) Linking a balanced scorecard to company strategy. Corporate Controler, Winter 24-29.

22. Mason, Jennifer (1996) Qualitative research. SAGE Publ. London.

23. Meindl James, Stubbart, Charles Porac, Joseph (ed) (1996) Cognition within and between organizations. SAGE Publ. London.

24. Miles Grant, Miles Raymond, Perrone Vincenzo, Edvinsson Leif (1998) Some conceptual and research barriers to the utilization of knowledge. California Management Review 40: 281-287.

25. Olve, Nils-Göran, Roy, Jan Wetter, Magnus (1997) Balanced Scorecard isvensk praktik. Liber Ekonomi, Malmö.

26. Roos Johan, Roos Göran, Edvinsson Leif, Dragonetti Nicola C (1997) Intellectual capital- Navigating in the new business landscape. MacMillan Press. London?

\section{Citation:}

Luisa Quintero Soto ML, González Velázquez LM, García Lirios C (2021) Intellectual Capital in the Post COVID-19. Ageing Sci Ment Health Stud Volume 5(1): 1-3. 